Rouse, and Mr. J. M. Thorp, of I.C.I. Pharmaceuticals Limited. We would like to thank Dr. W. Brass, of the London School of Hygiene, for his statistical advice in the initial stages of the trial. This trial was partly financed by a grant from the Scottish Home and Health Department through the Advisory Committee on Medical Research.

Reserve Tables and Reserve Figures and working protocols can be obtained on request. Reprint requests to $\mathrm{Dr}$. M. F. Oliver, Department of Cardiology, Royal Infirmary, Edinburgh EH3 9YW.

\section{References}

Ahrens, E. H. (1971). Proceedings of the IV International Symposium on Drugs Affecting Lipid Metabolism. In press.

Frank, C. W., Weinblatt, E., and Shapiro, S. (1970). Atherosclerosis, ed. R. J. Jones. Berlin-New York, Springer-Verlag.

Gilbert, J. B., and Mustard, J. F. (1963). Journal of Atherosclerosis Research, $3,623$.

Green, K. G., Inman, W. H. W., and Thorp, J. M. (1963). Fournal of Atherosclerosis Research, 3, 593 .

Hellman, L., et al. (1963). Journal of Atherosclerosis Research, 3, 454.

\title{
Secondary Prevention Trials using Clofibrate: A Joint Commentary on the Newcastle and Scottish Trials
}

\author{
H. A. DEWAR, M. F. OLIVER
}

British Medical fournal, 1971, 4, 784-786

\section{Introduction}

The design, conduct, and results of two trials in which an attempt was made to reduce the incidence of infarct and death in patients with ischaemic heart disease are reported on pages 767 and 775 of this issue. This joint commentary is intended to emphasize the salient points of difference and concurrence between the trials established in Newcastle and in Scotland.

\section{Differences in Design}

The main points of difference in design are listed in Table I. In the Scottish trial patients with angina were admitted only if the duration of angina was between 3 and 24 months. In the Newcastle trial no such limits were set. In the Scottish trial patients with myocardial infarction were admitted between 8 and 16 weeks after their first infarct. In the Newcastle trial patients were admitted at any time from six weeks after their last myocardial infarct and no limit was set on the number of previous infarcts. The inclusion in the Scottish trial of patients recovering from recent myocardial infarction might favour a worse short-term prognosis. In the Newcastle trial there were many patients with more than one myocardial infarction and their long-term prognosis is likely to have been worse.

\section{Differences in Conduct}

The main points of difference in conduct are listed in Table II. In the Newcastle trial sudden death was defined as death

Royal Victoria Infirmary, Newcastle upon Tyne NE1 4LP H. A. DEWAR, M.D., F.R.C.P., Consultant Physician and Cardiologist

\section{Royal Infirmary, Edinburgh EH3 9YW}

M. F. OLIVER, M.D., F.R.C.P., Consultant Physician, Department of Cardiology; and Reader in Medicine, University of Edinburgh
Honey, G. E., and Truelove, S. C. (1957). Lancet, 1, 1209.

Juergens, J. L., Edwards, J. E., Achor, R. W. P., and Burchell, H. B. (1960). Archives of Internal Medicine, 105, 444

Kagan, A., Dawber, T. R., Kannel, W. B., and Revotskie, N. (1962).

Langer, T., and Levy, R. I. (1968). New England fournal of Medicine, $279,856$.

Little, J. A., Shanoff, H. M., Row, R. D., Csima, A., and Yano, R. (1965). Circulation, 31, 854

Oliver, M. F. (1962). Lancet, 1, 1321.

Oliver, M. F. (1963). Fournal of Atherosclerosis Research, 3, 679.

Paterson, J. C., Armstrong, R., and Armstrong, E. C. (1963). Circulation, $27,229$.

Pell, S., and D'Alonzo, C. A. (1963). Fournal of the American Medical Association, 185, 831

Smith, A. F., Macfie, W. G., and Oliver, M. F. (1970). British Medical fournal, $2,86$.

Srivastava, S. C., Smith, M. J., and Dewar, H. A. (1963). Fournal of Atherosclerosis Research, 3, 640.

Stamler, J. (1964). Connecticut Medicine, 28, 675.

Truett, J., Cronfield, J., and Kannel, W. (1967). Fournal of Chronic Diseases, 20, 511. Public Health and the Nation's Health, 61, 831.

Westlund, K., and Nicolaysen, R. (1966). Scandinavian Fournal of Clinical and Laboratory Investigation, 18, Suppl. 87.

World Health Organization (1959). Technical Report Series, No. 168. Federation Proceedings, Suppl. 11, p. 52

Weinblatt, E., Shapiro, S., and Frank, C. W. (1971). American fournal of

that was immediate or within a few minutes of symptoms. In the Scottish trial the sudden death category included deaths up to one hour.

TABLE I-Differences in Design between the Newcastle and Scottish Trials Newcastle Scottish

\begin{tabular}{l|l} 
(a) Clinical diagnosis only. Abnormal (a) Diagnosis confirmed by abnormal & (b)
\end{tabular} E.C.G. not insisted on

(b) Duration of more than 3 months but less than 2 years

\section{Previous myocardial infarcts}

(a) No limit on numbers

No formal criteria of diagnosis required

(c) Entry permitted after minimum period of 6 weeks

(d) Average interval between last myocardial infarct and entry into
trial was 1! years (2-99 months)

(a) Only one allowed

b) W.H.O. criteria of diagnosis and E.C.C.C.s evaluated by one

(c) Entry betwe

8 and 16 weeks

(d) Average interval between myocardial infarct and entry into
trial was 3 months (2-4 months) Electrocardiograms

Interpreted both on entry and on $\mid$ Interpreted on entry, at the time of \begin{tabular}{l|l} 
conclusion by participating physicians & $\begin{array}{l}\text { an event, and on conclusion by one } \\
\text { observer according to WH.O. }\end{array}$ \\
on own criteria
\end{tabular} on own criteri criteria

Anticoagulants

\begin{tabular}{|c|c|}
\hline $\begin{array}{l}\text { Discouraged. Results analysed with } \\
\text { and without this small group }\end{array}$ & Special group formed \\
\hline \multicolumn{2}{|c|}{ Age } \\
\hline $\begin{array}{l}\text { No lower limit } \\
\text { Upper limit } 65 \text { years }\end{array}$ & $\begin{array}{l}\text { Lower limit } 40 \text { years } \\
\text { Upper limit } 69 \text { years }\end{array}$ \\
\hline \multicolumn{2}{|c|}{ Blood Pressure } \\
\hline $\begin{array}{l}\text { Patients with B.P. } 200 / 100 \mathrm{~mm} \mathrm{Hg} \text { or } \\
\text { on treatment for hypertension excluded }\end{array}$ & $\begin{array}{l}\text { Only malignant hypertension } \\
\text { excluded }\end{array}$ \\
\hline \multicolumn{2}{|c|}{ Cholesterol } \\
\hline $\begin{array}{l}\text { Patients with levels of } 400 \mathrm{mg} / 100 \mathrm{ml} \\
\text { and/or xanthomata excluded }\end{array}$ & $\begin{array}{l}\text { No limits imposed (few exceeded } \\
400 \mathrm{mg} 100 \mathrm{ml} \text { ) }\end{array}$ \\
\hline
\end{tabular}

Cigarettes graded $1-10,11-20$, and $\mid$ Cigarettes graded $1-15$ and $>15 /$ day
$>20 /$ day $>20$ day

Clofibrate

Men received 1.6 or $2 \mathrm{~g}$ daily according to weight
received $1.6 \mathrm{~g}$ daily

Corn oil $\quad \mid \begin{aligned} & \text { according to weight. Women } \\ & \text { received } 1.6 \mathrm{~g} \text { daily }\end{aligned}$


TABLE II-Differences in Conduct between the Newcastle and Scottish Trials

Newcastle Definition of Sudden Death Scottish

By one "blind" observer defined as | By one "blind" observer defined as \begin{tabular}{l|l} 
death that was immediate or within & death within one hour \\
a few minutes of symptoms
\end{tabular}

$$
\begin{array}{l|l}
\multicolumn{2}{c}{\text { Categorization of New Infarcts }} \\
\begin{array}{l|l}
\text { By one "blind" observer by } \\
\text { arbitrary criteria into certain, } \\
\text { probable, and possible }
\end{array} & \begin{array}{l}
\text { By one "blind" observer into } \\
\text { definite and probable according to }
\end{array} \\
\text { W.H.O. criteria }
\end{array}
$$

Serious Intercurrent Diseases

Most cases withdrawn from trial $\mid \begin{aligned} & \text { Most cases retained in trial till } \\ & \text { death }\end{aligned}$

$$
\text { Smoking Habits }
$$
Checked on entry, during trial, and $\quad$ Checked on entry only
on its termination

$$
\text { Other Serum Lipids }
$$

Total esterified fatty acids estimated $\mid$ Not estimated

on entry and during trial. Lipoprotein

in later phases

\section{Summary of Results}

In order to make comparison easier the results of the two trials are summarized in Tables III and IV in similar form.

\section{DEATHS}

In the Newcastle trial (Table III) there was significant overall reduction in sudden deaths and in all deaths in the clofibratetreated group compared with the placebo group. This trend was evident in all categories admitted to the trial and was most pronounced in those who had angina alone and in those who had angina + myocardial infarction ("all anginas").

In the Scottish trial (Table IV) there was no significant overall reduction in sudden deaths or all deaths in the clofibratetreated group compared with the placebo group. In those patients presenting with angina, whether or not they had had an infarct before admission to the trial-that is, the category "all anginas"-there was significant reduction in sudden death and all deaths in the clofibrate-treated group.
Thus the trials concur in respect of mortality in patients with angina, whether an infarct had intervened or not.

The discordant findings in the overall results might be explained in part by the fact that there were more patients with infarction only admitted to the Scottish trial (143 clofibrate/ 139 placebo) compared with the Newcastle trial ( 55 clofibrate/ 60 placebo), and fewer patients with angina only or angina + infarction (Scottish, 121 clofibrate/134 placebo; Newcastle, 183 clofibrate/192 placebo). Since the beneficial effect of clofibrate in both trials is principally in the angina group, it is to be expected that the Newcastle trial would reflect this more in the overall results than the Scottish trial.

It is important to point out that the death rate in the placebo group in the Newcastle trial was greater than in the Scottish (Newcastle, 5.34/1,200 patient-months; Scottish, 2.97/1,200 patient-months). Since many patients in the Newcastle trial had multiple infarcts, it is more likely that a difference in mortality rates might be demonstrated. The very low mortality rate in the Scottish trial was not expected and is discussed in the report of this trial; with such a low annual mortality rate it is not surprising that clofibrate failed to reduce it further.

\section{NON-FATAL INFARCTS}

In both trials there was a favourable but not quite significant (Newcastle trial, $\mathbf{P}=0.055$; Scottish trial, $\mathbf{P}=0.1$ ) trend in the treated as compared with the placebo group, and this was more pronounced when there was a previous history of angina rather than infarction. When the results of both trials are combined a significant $(P=0.01)$ reduction in non-fatal infarcts was observed in the clofibrate group.

\section{ALL EVENTS}

In both trials there was a highly significant reduction in all events in the "all anginas" subcategory, and in the Newcastle

\begin{tabular}{|c|c|c|c|c|c|c|c|c|c|}
\hline \multirow[b]{2}{*}{ First Clinical Presentation } & \multirow[b]{2}{*}{ Regimen } & \multirow[b]{2}{*}{$\begin{array}{l}\text { No. in } \\
\text { Group }\end{array}$} & \multicolumn{3}{|c|}{ Deaths } & \multicolumn{2}{|c|}{ Non-fatal Infarct } & \multicolumn{2}{|c|}{ All Events } \\
\hline & & & $\begin{array}{l}\text { Sudden } \\
\text { Death }\end{array}$ & $\begin{array}{l}\text { Fatal } \\
\text { Infarct }\end{array}$ & \begin{tabular}{|c|} 
All Deaths \\
Rate $/ 1,200$ \\
Patient-months
\end{tabular} & No. & $\begin{array}{c}\text { Rate } / 1,200 \\
\text { Patient-months }\end{array}$ & No. & $\begin{array}{c}\text { Rate } / 1,200 \\
\text { Patient-months }\end{array}$ \\
\hline Angina & $\begin{array}{l}\text { Clofibrate } \\
\text { Placebo }\end{array}$ & $\begin{array}{l}183 \\
192 \\
\end{array}$ & $\underset{17 \ddagger}{6}$ & $\begin{array}{l}10 \\
19\end{array}$ & $\begin{array}{l}2 \cdot 66+ \\
5 \cdot 98+11\end{array}$ & $\begin{array}{l}23 \\
36\end{array}$ & $\begin{array}{l}3.67 \\
6.02 \\
\end{array}$ & $\begin{array}{l}41 \dagger \\
76 \dagger \\
\end{array}$ & $\begin{array}{c}6 \cdot 33+ \\
12 \cdot 00+\|\end{array}$ \\
\hline Myocardial infarction & $\begin{array}{l}\text { Clofibrate } \\
\text { Placebo }\end{array}$ & $\begin{array}{l}144 \\
151\end{array}$ & $\begin{array}{r}7 \\
16\end{array}$ & $\begin{array}{l}11 \\
15\end{array}$ & $\begin{array}{l}3.68{ }^{\dagger} \\
6 \cdot 22 \dagger\end{array}$ & $\begin{array}{l}24 \\
31\end{array}$ & $\begin{array}{l}4 \cdot 87 \\
6 \cdot 25 \\
\end{array}$ & $\begin{array}{l}44+ \\
66 \dagger \\
\end{array}$ & $\begin{array}{r}8.55 \dagger \\
12.47 \dagger \\
\end{array}$ \\
\hline All cases* & $\begin{array}{l}\text { Clofibrate } \\
\text { Placebo }\end{array}$ & $\begin{array}{l}244 \\
253\end{array}$ & $\begin{array}{c}9 \\
21+\end{array}$ & $\begin{array}{l}16 \\
23\end{array}$ & $\begin{array}{l}3 \cdot 07 \dagger \\
5 \cdot 34+\S\end{array}$ & $\begin{array}{l}30 \\
46\end{array}$ & $\begin{array}{l}3.68 \\
5.76\end{array}$ & $\begin{array}{l}57 \dagger \\
94 \dagger\end{array}$ & $\begin{array}{c}6 \cdot 75 \dagger \\
11 \cdot 10+\|\end{array}$ \\
\hline
\end{tabular}
trial the reduction remained significant in the overall results. In the Scottish trial there was no significant reduction in those with a past history of myocardial infarction alone.

TABLE III-Secondary Prevention of Ischaemic Heart Disease with Clofibrate. Newcastle ${ }^{\top}$ Trial. Four-year Figures

\begin{tabular}{|c|c|c|c|c|c|c|c|c|c|}
\hline \multirow[b]{2}{*}{ First Clinical Presentation } & \multirow[b]{2}{*}{ Regimen } & \multirow[b]{2}{*}{$\begin{array}{l}\text { No. in } \\
\text { Group }\end{array}$} & \multicolumn{3}{|c|}{ Deaths } & \multicolumn{2}{|c|}{ Non-fatal Infarct } & \multicolumn{2}{|c|}{ All Events } \\
\hline & & & $\begin{array}{l}\text { Sudden } \\
\text { Death }\end{array}$ & $\begin{array}{l}\text { Fatal } \\
\text { Infarct }\end{array}$ & \begin{tabular}{c|} 
All Deaths \\
Rate $/ 1,200$ \\
Patient-months
\end{tabular} & No. & $\begin{array}{c}\text { Rate } / 1,200 \\
\text { Patient-months }\end{array}$ & No. & $\begin{array}{c}\text { Rate/1,200 } \\
\text { Patient-months }\end{array}$ \\
\hline $\begin{array}{c}\text { Angina }>3 \text { and }<24 \\
\text { months' duration }\end{array}$ & $\begin{array}{l}\text { Clofibrate } \\
\text { Placebo }\end{array}$ & $\begin{array}{l}147 \\
167\end{array}$ & $\begin{array}{c}3 \\
14 \S\end{array}$ & $\begin{array}{l}5 \\
9\end{array}$ & $\begin{array}{l}1.50 \\
3.97 \S\end{array}$ & $\begin{array}{l}11 \\
20\end{array}$ & $\begin{array}{l}2 \cdot 13 \\
3 \cdot 78\end{array}$ & $\begin{array}{l}19 \\
43\end{array}$ & $\begin{array}{l}3 \cdot 63 \\
7 \cdot 75 \|\end{array}$ \\
\hline Myocardial infarction & $\begin{array}{l}\text { Clofibrate } \\
\text { Placebo }\end{array}$ & $\begin{array}{l}260 \\
263 \\
\end{array}$ & $\begin{array}{l}13 \\
15\end{array}$ & $\begin{array}{l}16 \\
11\end{array}$ & $\begin{array}{l}3 \cdot 40 \\
3 \cdot 21\end{array}$ & $\begin{array}{l}20 \\
33\end{array}$ & $\begin{array}{l}2.43 \\
3.95\end{array}$ & $\begin{array}{l}49 \\
59\end{array}$ & $\begin{array}{l}5 \cdot 73 \\
6 \cdot 82 \\
\end{array}$ \\
\hline All cases* & $\begin{array}{l}\text { Clofibrate } \\
\text { Placebo }\end{array}$ & $\begin{array}{l}350 \\
367\end{array}$ & $\begin{array}{l}15 \\
21\end{array}$ & $\begin{array}{l}19 \\
14\end{array}$ & $\begin{array}{l}2 \cdot 89 \\
2 \cdot 97+\end{array}$ & $\begin{array}{l}25 \\
41\end{array}$ & $\begin{array}{l}2 \cdot 20 \\
3 \cdot 45\end{array}$ & $\begin{array}{l}59 \\
79 \dagger\end{array}$ & $\begin{array}{l}5 \cdot 09 \\
6 \cdot 42+\end{array}$ \\
\hline
\end{tabular}

* Patients who were classified as having "angina + myocardial infarction" on entry into the trial are represented in both subcategories. The figures for "all cases" are therefore less than the totals obtained by adding the two subcategories.

+ Includes some deaths from congestive heart failure. See Table VIII of Newcastle Report.
In the placebo group a significant difference from the corresponding figure in the clofibrate group is indicated by $\ddagger P<0.05, \S P<0.02, \| P<0.01$.

TABle IV-Secondary Prevention of Ischaemic Heart Disease with Clofibrate. Scottish Society of Physicians Trial. Four-year Figures

*Patients who were classified as having "angina + myocardial infarction" on entry into the trial are represented in both subcategories. The figures for "all cases" are therefore less than the totals obtained by adding the two subcategories.

In the placebo group a significant difference from the corresponding figure in the clofibrate group is indicated by $\$ P<0.02, \quad P<0.01$. 


\section{SERUM LIPID LEVELS}

In the Newcastle trial there were fewer events in the clofibratetreated group compared with those given placebo regardless of whether the initial serum cholesterol was high or low, and regardless of whether the presenting history had been sne of angina or of infarction. In both groups those with high initial serum cholesterol levels had more events. In the Scottish trial, on the other hand, those with high initial cholesterol levels did not have more events than those with low ones. The benefits seen in the "all anginas" group was independent of the starting level of serum cholesterol. In the Newcastle trial a derived index of triglyceride-rich lipoproteins was obtained; the response of this to treatment did not correlate well with the beneficial effects of clofibrate.

\section{Conclusion}

Both trials agree in showing a significant reduction in mortality, especially in sudden deaths, and in total events when clofibrate was given to patients who had angina. In the Newcastle trial there was also a favourable trend for patients who entered the trial with a history of myocardial infarction only, but this was not evident in the Scottish trial. This inconsistency might be explained by the considerable difference between the trials in mortality rates in the placebo groups and in the selection of patients.

In both trials, and especially in the Newcastle trial, there was also a reduction in the incidence of non-fatal infarcts, and again this was more pronounced in patients with angina. Clearly clofibrate is more beneficial when there has been or there is continuing myocardial ischaemia than when there is only a history of infarct. Is seems to protect particularly against sudden death.

The effect of the drug in reducing serum lipids was maintained up to five years, but in neither trial has it been possible to prove that this effect and the improved prognosis are causally related. Whether the beneficial effect of clofibrate is related in some way to the preservation of blood flow to the ischaemic areas is speculative, but, of course, clofibrate has other mechanisms of action than reduction of plasma cholesterol and triglycerides, such as reduction of raised plasma free fatty acids, raised fibrinogen levels, and platelet adhesiveness, and an increase in fibrinolytic activity.

The lesson to be learnt from both trials seems clear. Clofibrate is a beneficial drug in the treatment of ischaemic heart disease in patients who first present with angina and in those who continue to have angina after myocardial infarction. An argument can be developed for the establishment of a larger trial of clofibrate specifically in patients with angina, stratified according to certain high-risk categories. However, the ethics of conducting this on a controlled basis would, in view of the results reported here, have to be appraised carefully.

The assembly and statistical analysis of these studies has been greatly aided by Dr. C. C. Downie and Dr. R. T. Rouse, of I.C.I. Pharmaceuticals Limited, and we wish to thank them for their advice.

Reprint requests to Dr. M. F. Oliver, Department of Cardiology, Royal Infirmary, Edinburgh EH3 9YW.

\title{
Clinical Trial of Mefruside, a New Diuretic
}

\author{
W. H. R. AULD, W. R. MURDOCH
}

British Medical fournal, 1971, 4, 786-788

\section{Summary}

A controlled clinical trial of a new diuretic-mefrusideis reported, in which it was compared with frusemide in $\mathbf{1 5}$ normal subjects and 15 patients with fluid retention. It was found to be an effective diuretic which, in the patients, produced a significantly greater excretion of water and electrolytes than an equal dose of frusemide. Its smooth prolonged action, maximal in the first 12 hours, made it of particular value for maintenance therapy. In a short-term trial on a further 15 hypertensive patients mefruside was shown to have a useful hypotensive action. The drug was well tolerated with minimal side effects.

\section{Introduction}

Since the introduction of an effective oral diuretic in the form of chlorothiazide (Novello and Sprague, 1957), a wide range of compounds differing in their chemical class and pharmacological effect has been developed. Recent reports of a new compoundmefruside-suggest that it has a prolonged mode of action and

Ballochmyle Hospital and Heathfield Hospital, Ayrshire

W. H. R. AULD, M.D., F.R.C.PATH., Consultant Biochemist

W. R. MURDOCH, F.R.C.P.GLASG., M.R.C.P., Consultant Physician produces salt and water loss with little potassium depletion in short-term experiments (Wilson and Kirkendall, 1970).

The chemistry of this compound has been described by Horstmann et al. (1967). It is 4-chloro- $N^{\prime}$-methyl- $N^{\prime}$ (2-methyltetrahydrofurfuryl)-benzene-1,3-disulphonamide, and bears some chemical resemblance to frusemide (see Formulae).

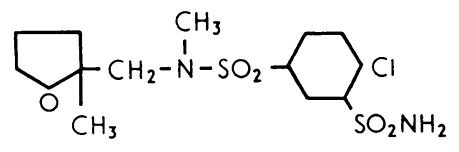

MEFRUSIDE

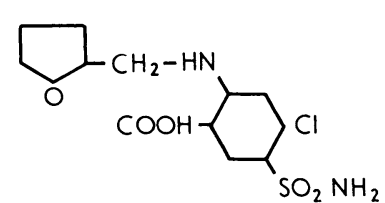

FRUSEMIDE
Its absorption, excretion, and metabolism has been studied by Duhm et al. (1967). It seems to act on the distal half of the nephron, inhibiting sodium and water reabsorption in the ascending loop of Henle and the collecting ducts (Meng and Kroneberg, 1967), in contradistinction to frusemide, which inhibits proximal reabsorption. Bicarbonate reabsorption is unchanged. The effect of the drug is dose-related up to about $100 \mathrm{mg}$ in human subjects but thereafter it seems to produce little further response (Schwab and Immich, 1967).

\section{Methods}

Powders containing either $50 \mathrm{mg}$ of mefruside or $50 \mathrm{mg}$ of frusemide were made up in the dispensary. The appearance and 